\title{
Reimagining the Royal Institution
}

The Royal Institution of Great Britain in London reopens this week after two years of renovations costing $£ 22$ million (US\$ 44 million). The eighteenth-century building now flaunts its heritage, spotlighting the scientists who worked there and discovered 10 chemical elements and claimed 14 Nobel prizes (see page 568). Architect Terry Farrell explains how he rethought the institution's ethos.

\section{You are a leader in ecology-based design and city planning. How does the natural world inspire your work? \\ I became interested in nature as a child and was a pupil of Ian McHarg, a pioneering naturalist and ecologist who taught landscape design at the University of Pennsylvania in Philadelphia. I have a great passion for communicating ideas, and enjoy books that explain complicated things, such as town planning or the sciences, by authors including Bill Bryson, Richard Dawkins and Matt Ridley. \\ Science informs my work - I am design champion for the Thames Gateway, the urban regeneration project stretching from east London to the Thames Estuary, and it is my ambition for this to be Britain's first eco-region. We have also designed many aquariums, including The Deep in Hull, UK, the Seattle Aquarium in Washington state and Biota! in London.}

\section{Famous scientists including Michael Faraday, Humphrey Davy and Lawrence Bragg worked at the Royal Institution. How did its history influence the renovations?} The project was led by the energy, drive and ambition of the institution's director, Susan Greenfield. We were closely at her side helping to rethink the building and its mission statement, and in doing so have managed to update and redefine the great history and great brand of the Royal Institution.

The historic fabric of the building was tired and run-down, its foundations were failing, the classic façade was in urgent need of repair and the services were in disarray. The richness of its history, such as the Nobel prizes won, the chemical elements discovered within it and the history of its growth, change and research projects were not apparent.

A careful balance was needed between preserving the building's history while adding new elements to give it freshness and vitality. It was not just a question of refurbishment, but of creating a new feeling and energy.

Over the centuries the building grew in an ad hoc way. How did you bring cohesion? A lot was achieved by opening up and connecting the spaces. There was no mental

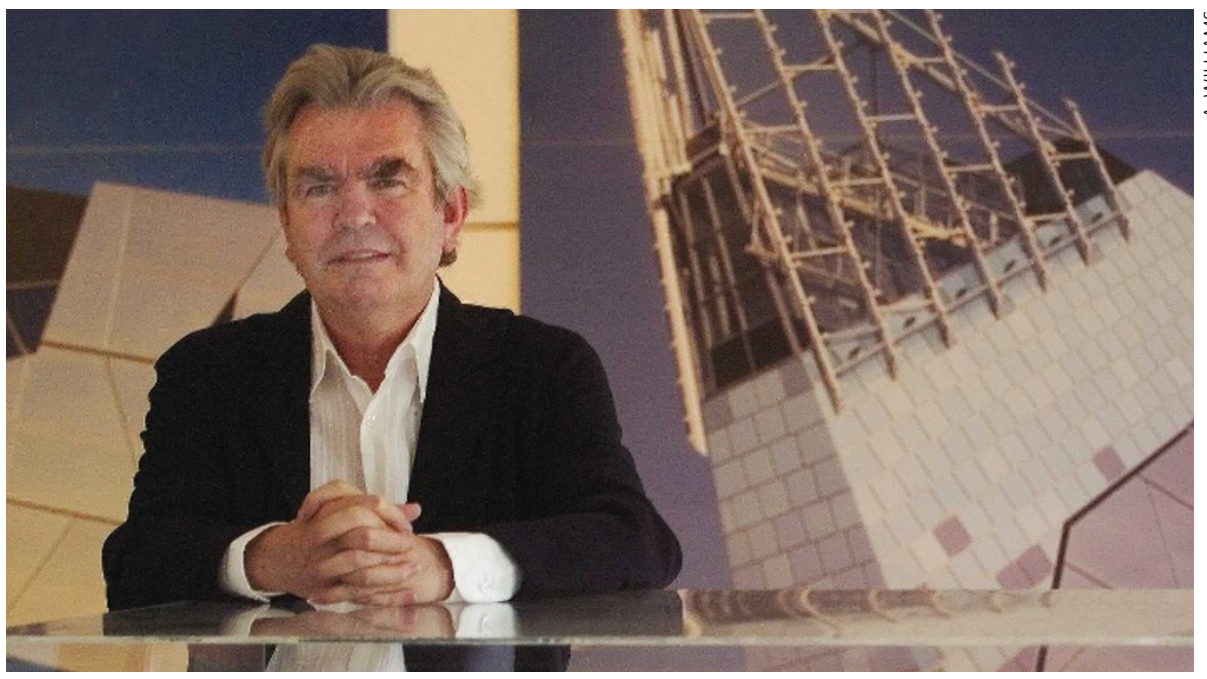

map of the building before, owing to its confused circulation system. The grand stair went only from the ground to the first floor, and two other staircases were tucked away at either end of the building - one had been nicknamed 'the sad staircase' because it was so neglected. A major part of the work was to implement a really good circulation system running primarily through the centre of the building, giving it a heart, a focus and a point of orientation. Vertical movement has been rationalized by introducing a new central lift within a glass atrium, spanning the whole height of the building.

The mission of the Royal Institution was realized by extending the exhibition areas and using the whole fabric of the building to show the collection of paintings and drawings. Displaying objects and telling the stories behind the artefacts led to a complete rethink of the exhibition area in the basement. The Faraday Theatre has been given a cooling system for hot weather and the auditorium seating rearranged because people are larger nowadays.

\section{How did you rethink the institution's purpose, given its many roles from research to outreach?}

One of the biggest changes in society is the democratization of learning and the need for accessibility to institutions by everyone: male or female, rich or poor, young or old. This modernity was achieved through a new kind of architecture, the transparent glass atrium, a glass lift, and through lighting, materials and freshness. And all this is done in a way that keeps the best of the old.

Extending the opening hours of the building will make visits longer, creating the possibility of meeting friends for coffee, dinner or drinks. It is a place for anyone to come and enjoy, not just for 'stuffy academic' types.

The children's laboratories and the televised annual Christmas lectures were a long-time commitment to the Royal Institution's outreach. A Young Scientists' Centre has been designed in the basement exhibition space, where children can perform experiments on heating, waste, lighting, power, gas, water, air and information technology.

The UK Science Media Centre is housed here and, through traditional and modern communication methods, will be able to respond to and be proactive on matters of scientific interest, connecting the institution's interests to the wider world.

Through all these interventions, we have reconfigured the Royal Institution not as a museum, but as a living, working, lively and engaging establishment.

Interview by Matt Brown, editor of http://network. nature.com, Nature's social networking site for scientists. 